\title{
Contents, Vol. 34, 1978
}

\section{No. 1-2}

Shaffer, T.H.; Koen, P.A.; Moskowitz, G.D.; Ferguson, J.D., and Delivoria-Papadopoulos, M.: Positive End Expiratory Pressure: Effects on Lung Mechanics of Premature Lambs ... 1 Hayashi, S.; Sanada, K.; Sagawa, N.; Yamada, N., and Kido, K.: Umbilical Vein-Artery Differences of Plasma Amino Acids in the LastTrimester of Human Pregnancy 11 Bender, J.W.; Davitt, M.K., and Jose, P.: Angio-tensin-I-Converting Enzyme Activity in Termand Premature Infants 19

Wamberg, S.; Hansen, A.C.; Engel, K., and Kilde-berg, P.: Balance of Net Base in the Rat. III.Effects of Oral Sodium Bicarbonate andSodium Citrate Loading 24

Hasty, D.L. and Murrell, L.R.: Development ofGlucose-Mediated Insulin Release Response inOrgan Cultured Rat Pancreas 32

Bryan, E.M.; Thorp, R.W., and Nicholson, E.:Serum Alphafetoprotein in Multiple Pregnancy 40

McLaughlin, P.J.; Zagon, I.S., and White, W.J.: Perinatal Methadone Exposure in Rats. Effects on Body and Organ Development . . 48

Hedner, T.; Lundborg, P., and Engel, J.: Effect of Hypoxia on Monoamine Synthesis in Brains of Developing Rats. III. Various 02 Levels . . 55

Kehrer, J.P. and Autor, A.P.: Relationship between Fatty Acids and Lipid Peroxidation inLungs of Neonates 61

Warszawski, D.; Gorodischer, R., and Kaplanski, J.: Comparative Toxicity of Caffeine andAminophylline (Theophylline Ethylene-diamine) in Young and Adult Rats 68 Bergman, L.; Westerberg, B.; Lindstedt, G., andLundberg, P.-A.: Possible Involvement ofGrowth Hormone in the Pathogenesis of EarlyNeonatal Hypocalcemia in Infants of DiabeticMothers 72

Tucci, P.L.; Biagioli, B.C., and Panero, C: Pro-teolytic Activity of Maternal Serum on Newborn IgD-Positive Lymphocytes. Study withProtease Inhibitors 80

Cheema, A.H. and Gilani, S.H.: Cardiac Myo-pathies in Neonatal Lambs: Histological andHistochemical Studies 84

Fenton, E.; Britton, H.G., and Hixon, D.A.†: TheSupply of Citrate to the Sheep Fetus 92 Lewis, A.B.; Nestor, L.; Dahms, B., and Platzker, A.C.G.: Cardiovascular Responses to Autonomic Blockade in Brain-Injured Fetal Lambs 97

No. 3-4

Corbier, P. and Roffi, J.: Pituitary Adrenocor-tical Response to Stress during the First Dayof Post-Natal Life in the Rat 105

Woods, J.R., jr.; Dandavino, A.; Nuwayhid, B.;Brinkman, C.R., III, and Assali, N.S.:

Cardiovascular Reactivity of Neonatal and AdultSheep to Autonomic Stimuli during Adrener-gic Depletion 112

Wamberg, S.; Hansen, A.C.; Engel, K., and Kilde-berg, P.: Balance of Net Base in the Rat.

IV.Effects of Oral Calcium and Phosphate Loading 121 
Shaughnessy, P.W.; DiGiacomo, R.F.; Martin, D.P., and Valerio, D.A.: Prematurity and Perinatal Mortality in the Rhesus (Macaca mulat-ta): Relationship to Birth Weight and Gestational Age 129

Elphick, M.C.; Edson, J.L.; Lawlor, J.P., andHull, D.: Source of Fetal-Stored Lipids duringMaternal Starvation in Rabbits $\quad 146$

Pascale, J.A.; Mims, L.C.; Greenberg, M.C., and Alexander, J.B.: Gastric Response in Low Birth Weight Infants Fed Various Formulas . 150

DeRoth, L. and Downie, H.G.: Basic Cardiavas-cular Parameters in the Underweight NeonatalSwine $\quad 155$

Coufalik, A. and Monder, C: Perinatal Development of the Tyrosine Oxidizing System ... 161

Roord, J.J.; Ramaekers, L.H.J., and Engelshoven, J.M.A. van: Intra-Uterine Malnutrition andSkeletal Retardation $\quad 167$

IV

Contents

208

Brown, J.D. and Vannucci, R.C.: Cerebral Oxida-tive Metabolism during Intrauterine GrowthRetardation 170

Leary, H.L., jr. and Lecce, J.G.: Effect of Feeding on the Cessation of Transport of Macromolecules by Enterocytes of Neonatal PigletIntestine 174

Glyman, R.I.; Maurary, F.; Wong, L.; Heymann, A., and Rudolph, A.M.: The Developmental Response of the Ductus arteriosus to Oxygen 177

Bourre, J.-M.; Gozlan-Devillierre, N.; Daudu, O., and Baumann, N.: Is There a Blood-

BrainRelationship for Saturated Fatty Acids duringDevelopment? 182

Gootman, P.M.; Buckley, N.M.; Gootman, N.;Crane, L.A., and Buckley, B.J.:

IntegratedCardiovascular Responses to Combined Somatic Afferent Stimulation in NewbornPiglets $\quad 187$

Winston, J.M. and Roberts, R.J.: Influence ofIncreasing Age on Lethality Induced by Carbon Monoxide or Hypoxic Hypoxia 199

Courtney, K.D. and Ebron, M.T.: Isozyme Profiles of Lactic Dehydrogenase and Creatine

Phosphokinase in Neonatal Mouse Hearts . . 203

Varia

No. 5-6

Clark, B.R.; Weichsel, M.R., jr., and Poland, R.E.:Correlation of DNA Accumulation Rate

withThymidylate Synthetase Activity in Developing Rat Cerebellum: Effect of Hypothy-roidism 209

Shand, J.H.; Noble, R.C., and Moore, J.H.: Dietary Influences on Fatty Acid Metabolism inthe Liver of the Neonatal Lamb 217

Antonowicz, I.; Ishida, S., and Shwachman, H.:Studies in Meconium in Cystic Fibrosis:

theActivities of alpha-D-Mannosidase, beta-Glucuronidase, beta-D-Fucosidase, Acid

andAlkaline Phosphatase 225

Elphick, M.C.; Edson, J.L., and Hull, D.: Effect of Maternal Glucose Infusions on Fatty Acid

Transport across the Placenta in Rabbits ... 231

Thibeault, D.W.; Emmanouilides, G.C., andDodge, M.E.: Pulmonary and CirculatoryFunction in Preterm Lambs Treated withHydrocortisone in utero 238 
Homes, F.A.; Everts, R.S., and Havinga, H.: TheDevelopment of DT-Diaphorase in Rat Liverand Its Induction by Benzo(a)pyrene 248

Robillard, J.E.; Sessions, C, and Smith, F.G., jr.: In vivo Demonstration of Renal Carbonic Anhydrase Activity in the Fetal Lamb .... 253

Ingvarsson, B.I.; Carlsson, R.N.K., and Karlsson, B.W.: Synthesis of $\alpha$-Fetoprotein, Albumin and Total Serum Protein in Neonatal Pigs . . 259

Parkinson, C.E.; Supramaniam, G., and Harvey, D.: Bubble Clicking in Pharyngeal

AspirateCompared with Lecithin/Sphingomyelin Ratio 269

Csaba, G. and Nagy, S.U.: The Binding of 125I-TSH to Thyroid Cell Receptors

PreviouslyDeformed (in Neonatal Age) by Gonado-tropin Treatment 275

Rundell, J.O. and Lecce, J.G.: Relationship ofIncorporation of Radioprecursors into Proteinand Phospholipids of the Plasmalemma ofGuinea Pig (Neonate) Intestinal Epitheliumand the Cessation of Uptake of Macromole-cules (Closure) 278

Jones, R.E.: Degradation of Radioactively Labelled Protein in the Small Intestine of theSuckling Rat 286

Meloni, T.; Costa, S.; Corti, R., and Cutillo, S.:Agar in Control of Hyperbilirubinemia ofFullTerm Newborn Infants with ErythrocyteG-6-PD Deficiency 295

Hemberger, J.A. and Schanker, L.S.: Effect ofThyroxine on Permeability of the NeonatalRat Lung to Drugs 299

A. Author Index 304

Subject Index 306 